\title{
Evolution and Application of the Brazilian Legislation for the Traffic of Tractors on Public Roadways
}

\author{
Sabrina Dalla Corte Bellochio ${ }^{1}$, Gessieli Possebom ${ }^{1}$, Francieli de $\operatorname{Vargas}^{1}$, Lutiane Pagliarin ${ }^{2}$, Vitor Pires Scherer ${ }^{1}$ \\ \& Airton dos Santos Alonço ${ }^{1}$ \\ ${ }^{1}$ Federal University of Santa Maria, Santa Maria, RS, Brazil \\ ${ }^{2}$ Mechanical Engineer, Santa Maria, RS, Brazil \\ Correspondence: Sabrina Dalla Corte Bellochio, Federal University of Santa Maria, Avenida Roraima, 1000, \\ Centro de Ciências Rurais, $3^{\circ}$ andar, sala 3325, CEP 97105-900 Santa Maria, RS, Brazil. E-mail: \\ bellochiosabrinad@hotmail.com
}

Received: November 25, 2017

Accepted: January 19, 2018

Online Published: February 15, 2018

doi:10.5539/jas.v10n3p317

URL: https://doi.org/10.5539/jas.v10n3p317

The research is financed by $C N P Q$.

\begin{abstract}
The evolution of Brazilian agricultural mechanization increased, within with the cultivated area, searching to satisfy the demand for food. The agricultural tractor is the main source of power in meeting this demand. However, due to its increasing use, incidents have been observed in public roadways. The lighting and signaling elements of these machines are critical in preventing these occurrences, and there is, in Brazil, legislation in this area, the CONTRAN (National Traffic Council) and the Ministry of Labor. The objective of this study was to demonstrate the evolution and application of the Brazilian law for the lighting and signaling requirements for tractors on public roads traffic and relate these aspects to scientific studies relevant to the topic. Through the study, it was observed that there was an evolution in the Brazilian legislation, especially since 2014, with the term of CONTRAN Resolution no. 454. From this evolution, there was misalignment between the items required by the different legislative bodies on the subject and, in addition, the provisions from both the CONTRAN and the Ministry of Labor have no technical and/or dimensional requirements relative to the location of items on the machine. The scientific studies analyzed showed that there was also progress in the implementation of legislation in new agricultural tractors. However, it is not enough for the machine to leave the factory in a proper way, it must be maintained in working conditions for its operation. Finally, it was observed the need for the implementation of awareness campaigns on the context of road safety and the use of methods for assessing their effectiveness.
\end{abstract}

Keywords: accidents, lighting and signaling, highway, mechanization

\section{Introduction}

The world population is growing and, consequently, it increases the demand for food in the world (Gergoletti, 2008), making it necessary the use of technologies in agricultural production, given that they contribute significantly so that we can meet such a need (Matos \& Pessôa, 2011). Thus, aiming at sustainability and food security, the Brazilian agricultural production needed to be optimized (Molin, Amaral, \& Colaço, 2015). This occurred with the increase in cultivated area, clearing of agricultural borders, implementation of new technologies and farming practices. The combination of these techniques enabled the production scale, turning Brazil into one of the major producers of soybeans in the world (Espíndola \& Cunha, 2015); and still has the potential to increase its agriculture production by $40 \%$ by the year 2019 , according to Vieira Filho, Gasques, and Sousa (2011).

The mechanization in Brazilian agriculture has followed the development of agricultural borders since the manufacturing of the first national tractors units in 1960. The new scale production scenario demanded tractors with more power and technological innovation, in the pursuit for higher productivity and reduction of production cost (Ferreira Filho \& Felipe, 2007; Oliveira, 2000; Melo, 2012; Vian et al., 2013; Silva Junior, 2017). This reality required a renewal of the tractor fleet to provide compatibility, since they cannot be adapted to older 
machines (Ferreira Filho \& Felipe, 2007; Vian et al., 2013). This way, Brazil presented in 2016 the newest tractor fleet composition of the past 29 years, with more than half of the machines with up to ten years of use, according to Bellochio et al. (2017).

The tractor is characterized as the main source of power for rural areas (Rinaldi et al., 2016), being widely used in agricultural activities. The increasing use of tractors in the agricultural mechanization process caused the evolution of safety measures. On the other hand, incidents remained. According to Silva (2015), the use of tractors contributes to placing the agricultural activity among the ones with the highest risk of accidents, and Fernandes et al. (2014) point out that working with tractors is highly susceptible to accidents. In addition, the International Labor Organization (ILO) highlights that about one in three rural work accidents involving agricultural machinery result in worker's permanent disability (ILO, 2004).

Work incidents are of enormous social and economic importance. Statistical studies have shown the seriousness of this problem, either for their incidence, or the age of the injured, or their consequences. These accidents are becoming increasingly common not only in farms but also on highways, due to the constant traffic of agricultural machinery between production areas, to change the workplace or to transport goods and supplies (Monteiro, 2010).

As for the intensification of tractors displacement on public roads, Greenan et al. (2016) observed that the increase in the risk of collisions with farm machinery is related to the increase in the annual average number of vehicles circulating daily on American highways in the state of Iowa. When comparing the number of accidents involving tractors to the number of accidents involving passenger vehicles and transportation, the values are lower. However, when comparing the severity of the accident, those involving agricultural tractors show higher values than other vehicles. This fact shows the high degree of danger that these accidents represent (ANSR, 2014; Monteiro, 2014).

The elements of lighting and signaling of agricultural machinery are essential in preventing accidents on public roads. In a study in the American agricultural areas, Ramirez et al. (2016) show that the greater the compliance of agricultural machinery with the requirements of ASABE lighting and signaling standards, the less likely they are to be involved in accidents on public roads.

There are in Brazil, legislating in this area, the CONTRAN (National Traffic Council) and the Ministry of Labor (MTE). Thus, the aim of this study was to demonstrate the evolution and application of Brazilian law for the lighting and signaling requirements of tractors for the traffic on public roads, as well as to relate these aspects to scientific studies relevant to the topic.

\section{Brazilian Legislation on Agricultural Tractors Lighting and Signaling for Traffic on Public Roadways}

\subsection{Brazilian Traffic Law}

Conceição (2017) conducted a retrospective study related to the legislation that deals with the traffic issue in the country. The study highlights Decree number 8,324, from 1910, as the first on the subject, being promulgated about a decade after the arrival of the first car in Brazil. From this point came the need to expand and further detail the laws, when in 1941 it was approved the first National Traffic Code by Decree-Law number 2,994, with wording altered in the same year by Decree-Law number 3,651, where the National Driver's License $(\mathrm{CNH}$, in Portuguese) became mandatory. In 1966, there was the adoption of the second National Traffic Code, by Law no. 5,108 and 31 years later, in 1997, under the Law no. 9,503, it was set up the CTB (Brazilian Traffic Code), currently in effect. This evolution is shown in Figure 1.

Table 1. Chronological evolution of Brazilian traffic law

\begin{tabular}{|c|c|c|c|}
\hline \multicolumn{4}{|c|}{ Traffic law } \\
\hline Year & Event & Legislation & Situation \\
\hline 1900 & First car in Brazil & - & - \\
\hline 1910 & First Brazilian legislation concerning traffic & Decree no. 8,324 , of October $27^{\text {th }}, 1910$ & - \\
\hline 1941 & First National Traffic Code & Decree-Law no. 2,994 , of January $28^{\text {th }}, 1941$ & - \\
\hline 1941 & Change in the wording of the National Traffic Code & Decree-Law no. 3,651, of September $11^{\text {th }}, 1941$ & - \\
\hline 1966 & According to National Traffic Code & Law no. 5,108 , of September $21^{\text {st }}, 1966$ & - \\
\hline 1997 & CTB - Brazilian Traffic Code & Law no. 9503 , to September $23^{\text {rd }}, 1977$ & In force \\
\hline
\end{tabular}

Source: Adapted from Conceição (2017). 
In view of the technological evolution, the increasing population and vehicle fleet, as well as the interrelationships of traffic and the number of accidents, it is necessary to demand that the competent bodies are aware of the changes to innovate and adapt the legislation to this reality. In this sense, the CTB has already undergone several amendments, mainly related to mandatory equipment. In 1998, the CONTRAN (National Traffic Council) Resolution no. 14 (1998) came into force, establishing mandatory equipment for the fleet of vehicles in circulation, thus to be able to circulate on public roads the vehicles should provide the required equipment, to be found by the inspection in working order. The scope of this resolution includes the following categories of vehicles, according to DENATRAN (2017):

$>$ Automotive vehicles and electric buses;

$>$ Trailers and semi-trailers;

$>$ Mopeds;

$>$ Scooters, motorcycles and tricycles;

$>$ Four-wheelers;

$>\quad$ Wheeled and mixed tractors and

$>$ Track-type tractors.

Referring to tractors, this resolution remained unchanged until the end of 2013, when it was replaced by CONTRAN Resolution no. 454 (2014), currently in force and which comprises a further array of items in the subject compared to the previous resolution. Figure 2 shows the chronological evolution of resolutions related to the equipment required for tractors.

Table 2. Chronological evolution of the resolutions related to mandatory equipment for tractors to circulate on public roads

\begin{tabular}{|c|c|c|c|c|}
\hline \multirow[b]{2}{*}{ Year } & \multicolumn{3}{|c|}{ Mandatory equipment-CTB } & \multirow[b]{2}{*}{ Mark } \\
\hline & Event & Legislation & Situation & \\
\hline 1998 & $\begin{array}{l}\text { CONTRAN } \\
\text { Resolution no. } 14\end{array}$ & $\begin{array}{l}\text { Law no. } 9,503 \text { of } \\
\text { September } 23^{\text {rd }}, 1997 \\
\text { Decree no. } 2,327 \text { of } \\
\text { September } 23^{\text {rd }}, 1997\end{array}$ & $\begin{array}{l}\text { Increased by Resolutions no. } 34 / 98 \text {, } \\
43 / 98,87 / 99 \text { and } 44 / 98,46 / 98 \text { and } \\
\text { 129/01. Altered by Resolutions no. } \\
87,228,259 \text { and } 592 / 16\end{array}$ & $\begin{array}{l}\text { Establishes mandatory equipment for } \\
\text { the fleet of vehicles in circulation and } \\
\text { other measures (includes wheeled and } \\
\text { track-type tractors). }\end{array}$ \\
\hline 2014 & $\begin{array}{l}\text { CONTRAN } \\
\text { resolution no. } 454\end{array}$ & $\begin{array}{l}\text { Law no. } 9,503 \text { of } \\
\text { September } 23^{\text {rd }}, 1997 \\
\text { Decree no. } 4,711 \text {, of } \\
\text { May } 29^{\text {th }}, 2003\end{array}$ & In force & $\begin{array}{l}\text { Alters the CONTRAN Resolution no. } \\
14 \text { to establish new safety items and } \\
\text { dimensions for agricultural and } \\
\text { construction tractors, among others, } \\
\text { capable of transiting on public roads. }\end{array}$ \\
\hline
\end{tabular}

Source: Adapted from DENATRAN (2017).

\subsection{Brazilian Legislation on Occupational Health and Safety}

In addition to the CTB, the Ministry of Labor and Employment also has legislation on safety and lighting items in tractors. Law no. 6,514 of 1977 approves the NRs (Regulation Rules) on Occupational Safety and Medicine. Discussing the issue, NR 31 (2005) and NR 12 (2010) are highlighted.

The Regulation Rules (NR) on occupational safety and health are obligatory for private and public companies and public agencies of direct and indirect administration, as well as the bodies of the legislative and judiciary that have employees covered by the CLT (Consolidation of Labor Laws). Failure to comply with laws and regulations on safety and health at work will cause to the employer the application of the penalties provided in the legislation (MTE, 2017).

The NR 31 (2005), published in 2005, concerns occupational safety and health in agriculture, livestock, silviculture, forestry and aquaculture. This provides, among others, general principles for agricultural machines. With respect to lighting, self-propelled machines manufactured from May 2008 must have the following items: headlights, position taillights, horn, rear view mirror and automatic reverse beep coupled to the transmission system. The self-propelled machines manufactured before this date must have headlights and horn. 
In this sense, the NR 12 (2010), referring to Safety in Machinery and Equipment, also addresses this issue. This rule has undergone several updates and, in the review published in 2010, in order to cover and specify machines and applications sets, included such items for the lighting of agricultural tractors. Thus, it is possible to see in Figure 3 the chronological evolution of the Regulation Rules in the aspect related to the lighting of agricultural tractors.

Table 3. Chronological Evolution of the Regulation Rules related to lighting in tractors

\begin{tabular}{|c|c|c|c|}
\hline \multicolumn{4}{|c|}{ Mandatory equipment-MTE } \\
\hline Year & Event & Legislation & Mark \\
\hline 1977 & NR (Regulation Rules) & $\begin{array}{l}\text { Approved by Law no. } 6,514 \text {, of December } \\
22^{\text {nd }}, 1977 \text {, through Ordinance no. } 3,214 \text {, } \\
\text { of June } 8^{\text {th }}, 1978\end{array}$ & $\begin{array}{l}\text { No specific requirements of lighting for } \\
\text { tractors }\end{array}$ \\
\hline 2005 & $\begin{array}{l}\text { Establishes the NR 31: } \\
\text { Occupational Safety and Health } \\
\text { in Agriculture, Livestock, } \\
\text { Silviculture, Forestry and } \\
\text { Aquaculture }\end{array}$ & $\begin{array}{l}\text { MTE Ordinance no. } 86 \text { of March } 3^{\text {rd }}, 2005 \\
\text { Undergoes changes: } \\
\text { MTE Ordinance no. } 2,546 \text {, of December } \\
14^{\text {th }}, 2011 \\
\text { MTE Ordinance no. } 1,896 \text {, of December } \\
9^{\text {th }}, 2013\end{array}$ & $\begin{array}{l}\text { It establishes, among others, general lighting } \\
\text { principles for agricultural machinery } \\
\text { manufactured from May } 2008\end{array}$ \\
\hline 2010 & $\begin{array}{l}\text { Review of NR 12: Safety in } \\
\text { Machines and Equipment }\end{array}$ & $\begin{array}{l}\text { Annex inserted by MTE Ordinance no. } \\
197 \text { of December } 17^{\text {th }}, 2010\end{array}$ & $\begin{array}{l}\text { Adds Annex XI relating to machines and } \\
\text { implements for agricultural and forestry use, } \\
\text { which aligns with the NR } 31 \text { the general } \\
\text { principles of lighting for agricultural } \\
\text { machinery manufactured from May } 2008\end{array}$ \\
\hline
\end{tabular}

2.3 Items Related to Lighting and Signaling in Tractors, According to the Legislation Requirements of CONTRAN and Ministry of Labor and Employment

Based on the evolution of the legislation aspects on this area, it is possible to draw a parallel comparison between the requirements of the different regulations from CONTRAN and Ministry of Labor and Employment (MTE) with their in force period, seen in Figure 1.

\begin{tabular}{|l|l|l|l|l|}
\cline { 2 - 5 } \multicolumn{1}{c|}{} & $\begin{array}{l}\text { CONTRAN } \\
\text { Resolution no. 14 }\end{array}$ & MTE NR31 & MTE NR12 & $\begin{array}{l}\text { CONTRAN } \\
\text { Resolution no. 454 }\end{array}$ \\
\hline Period in force & $\begin{array}{l}\text { From February 1998 } \\
\text { to December 2013 }\end{array}$ & $\begin{array}{l}\text { From March } \\
\text { 2005-Present }\end{array}$ & $\begin{array}{l}\text { From December } \\
\text { 2010-Present }\end{array}$ & $\begin{array}{l}\text { From January } \\
\text { 2014-Present }\end{array}$ \\
\hline Headlights & $\mathbf{X}$ & $\mathbf{X}$ & $\mathbf{X}$ & $\mathbf{X}$ \\
\hline Position taillights & $\mathbf{X}$ & $\mathbf{X}$ & $\mathbf{X}$ & $\mathbf{X}$ \\
\hline Brake lights & $\mathbf{X}$ & - & - & $\mathbf{X}$ \\
\hline Reverse lights & - & - & - & $\mathbf{X}$ \\
\hline $\begin{array}{l}\text { Automatic audible reverse signal } \\
\text { coupled to the transmission system }\end{array}$ & - & $\mathbf{X}$ & $\mathbf{X}$ & $\mathbf{X}$ \\
\hline Horn & - & $\mathbf{X}$ & $\mathbf{X}$ & $\mathbf{X}$ \\
\hline Turn signal lights, front & $\mathbf{X}$ & - & - & $\mathbf{X}$ \\
\hline Turn signal lights, rear & $\mathbf{X}$ & - & $\mathbf{X}$ \\
\hline Hazard lights & - & - & - & $\mathbf{X}$ \\
\hline Back plate lighting & - & - & - & $\mathbf{X}$ \\
\hline Retro Reflective tapes & - & - & $\mathbf{X}$ \\
\hline Rearview mirror & $\mathbf{X}$ & $\mathbf{X}$ & $\mathbf{X}$ \\
\hline Seat belt & - & $\mathbf{X}$ & $\mathbf{X}$ & $\mathbf{X}$ \\
\hline Rollover protective structure (ROPS) & - & $\mathbf{X}$ & $\mathbf{X}$ \\
\hline
\end{tabular}

Figure 1. Comparison of legislative requirements of CONTRAN and MTE for items related to lighting and signaling in tractors 
The data analysis shows that the CONTRAN legislation has become more comprehensive over the years, having a greater range in lighting and signaling requirements of tractors when in traffic on public roadways. Currently, the amount of items required by Resolution no. 454 (2014), which is in force, is $216 \%$ higher than Resolution no. 14 (1998), which lasted until the end of 2013. The added items were related to lighting and reverse sound signal, horn, turn signals, rear plate lighting, retro-reflective tapes and seat belt.

Regarding the MTE, the requirements in this area, given by NR 31 (2005) and NR 12 (2010), are more recent, becoming effective in 2005 and 2010, respectively. As for the number and content of the requirements, they are equivalent in the two regulations and the items are contained in the resolution CONTRAN no. 454 (2014), except for the rollover protective structure. However, they present a significantly lesser extent as compared to the CONTRAN no. 454 (2014) resolution, being similar to the former resolution CONTRAN no. 14 (1998).

\section{Brazilian Scientific Research Related to Compliance of Lighting and Signaling Items in Tractors}

\subsection{Assessment of Lighting and Signaling Items in New Tractors and in Use, Prior to 2005}

From the legal aspect, it is possible to analyze the scientific studies that carried out the verification in the field of the presence of lighting and signaling items in tractors in use and in new tractors, over the years.

In this regard, Correa et al. (2005) evaluated the safety conditions of 487 tractors in use in 270 properties and 31 new tractors available in dealerships and on display at agricultural fairs in São Paulo state, from August 2000 to December 2001. They found that the tractors in use do not favor the safety and comfort of the operator, while new tractors show a tendency to fulfill the safety and comfort requirements, having as favorable points, in most cases, the requirements for traffic on highways. Out of these, the device which was most often available in the analyzed tractors is the headlight. It can be seen in Figure 2 a comparison of the percentage of presence of the analyzed items, for the traffic on public roads, of tractors in use and tractors available to the market in 2001.

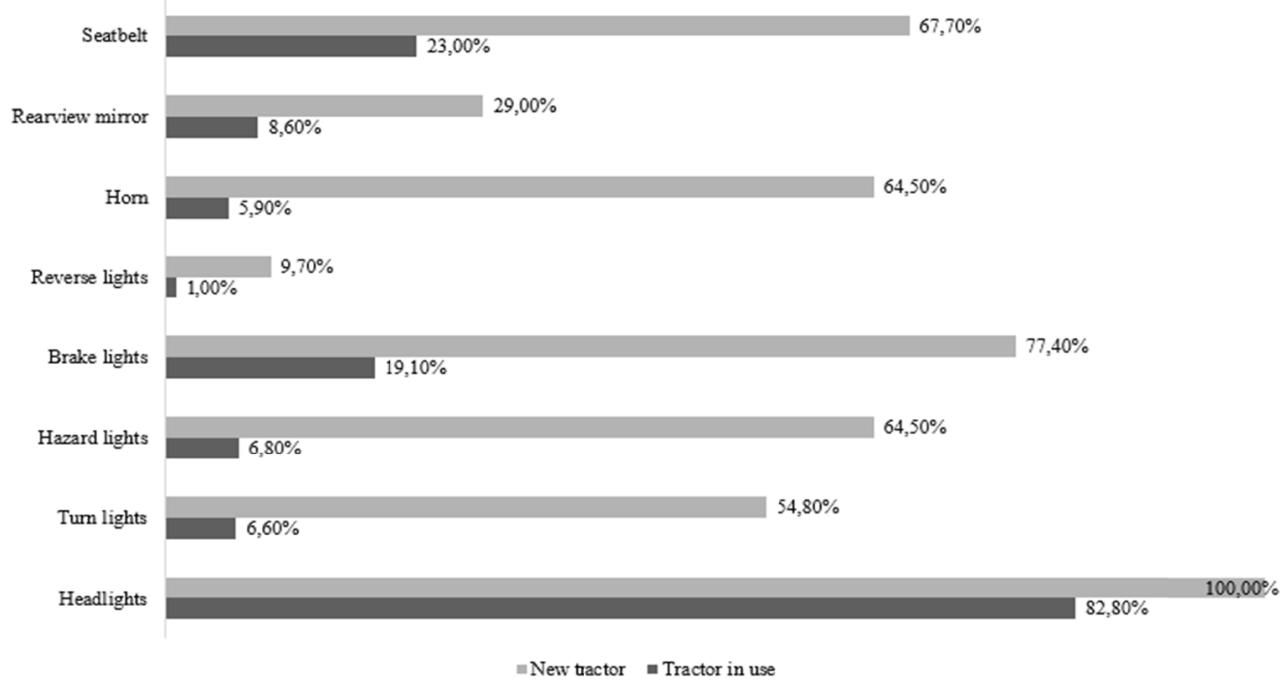

Figure 2. Presence percentage of the requirements for traffic on highways, in 2001, in the state of Sao Paulo, in 487 tractors in use and 31 new tractors

Source: Adapted from Correa et al. (2005).

It was observed that the new tractors available in the market did not meet in their entirety at least two of the lighting requirements of the time. In addition, only the headlight was present in all new tractors, the item with the largest percentage also in used ones, with $82.80 \%$. On the other hand, the reverse light represented the lowest indexes present within the analysis both for new tractors as for used ones, with $9.70 \%$ and $1.00 \%$, respectively.

\subsection{Ergonomics and Safety Coefficient of Agricultural Tractors}

Debiase et al. (2004) created a coefficient of ergonomics and safety for agricultural tractors and applied it in 175 tractors in use in 114 properties in the state of Rio Grande do Sul, in the municipalities of Santa Maria, Restinga Seca and Cachoeira do Sul. Of the items related to lighting standards, the ones evaluated were the presence of headlights; taillights; work light; brake lights; reverse light; turn indicators; hazard lights; backrest; horn; 
rearview mirror and seat belt. In the sampled tractors, the overall average index was less than 35 on a scale up to 100 , what characterizes poor conditions related to lighting and signaling in the agricultural tractors covered by the survey.

\subsection{Lighting Information in Technical Catalogs}

As for the information contained in the catalogs of the machines, a study was conducted by Francetto et al. (2010) through the creation of a data bank with the available data from the websites of 9 brands and 141 models. From the assessment of the technical information provided by the national tractor manufacturers, the authors concluded that the data do not allow a technical comparison between models and that there is no standard among companies, and the pieces of information related to the lighting items are among ones with the highest lack of information provided by the manufacturers.

\subsection{Evaluation of the Conservation Status of Lighting Items and Aspects Related to the Operator}

Additionally, Flores et al. (2015) demonstrated through a questionnaire applied to 35 operators, visiting 27 farms in the Zona da Mata of Minas Gerais, in 2013, that 100\% of tractors in use (37\% were manufactured from 2010 on) are not identified with sound or light hazard signaling alert, front and rear. Additionally, $18 \%$ of turn signal lights and $9 \%$ of the headlights were not working properly. Still, more than $60 \%$ of respondent operators transit on public roads with farm machinery, $26 \%$ do not have a driver's license and $60 \%$ did not know the rules of the Brazilian Traffic Code for the transport and driving farm machinery on public roads. These results confirm that the machines left the factories without any state inspection, without complying to the regulation rules in force at the period, as in this period the rules that established the standards for reverse lighting and sound signaling attached to the gearbox transmission, position taillights, rear and front turn signal lights, were already in force.

\subsection{Evaluation of the Presence of Lighting Items in New Tractors in the Year 2017}

Recently, Barbieri (2017) evaluated the compliance of operating stations for agricultural tractors safety and ergonomic standards (comprised wheeled tractors with power over $50.1 \mathrm{hp}$, superior gauge to $1280 \mathrm{~mm}$ and 600 $\mathrm{kg}$ minimum weight, new, with original factory safety features, available in the Brazilian market until the month of September 2016). With regard to NR 12 (2010), regarding the mandatory lighting and signaling items that should be present in the operation station of agricultural tractors, such as: reverse beep signal, seatbelt, rearview mirror, ROPS and horn, it was found that all were present in the 34 operating stations evaluated. This figure, when compared to previous studies, shows the evolution of compliance to the legislative aspect of this issue in Brazil, where, currently, the requirements of lighting and signaling of tractors are provided by the factories and available to the buyer of the product.

\section{Conclusions}

There has been an evolution in the Brazilian legislation for the lighting and signaling requirements of tractors for their traffic on public roadways, especially from the year 2014, with greater coverage of the items over the period in force of CONTRAN Resolution no. 454 (2014). From this evolution, there was the misalignment between the items required by the different legislative bodies on the subject and, in addition, the provisions of both the Ministry of Labor and the CONTRAN do not present technical and/or dimensional requirements relative to the location of items on the machine.

The scientific studies analyzed showed that there was also progress in the implementation of the legislation in new agricultural tractors. However, it is not enough for the machine to leave the factory with the lighting and signaling requirements, as they must be used and maintained in working conditions for its operation.

Finally, it was observed the need for the implementation of awareness campaigns in the context of road safety and the use of methods for assessing their effectiveness.

\section{References}

ANSR (Autoridade Nacional de Segurança Rodoviária). (2014). Ficha temática de veículos agrícolas 2004 a 2013. Retrieved from http://www.ansr.pt/Estatisticas/FichasTematicas/Documents/2014/FICHA\%20TEMÁ TICA\%20-\%20TRACTOR\%20AGRÍCOLAS.pdf

Barbieri, J. P. (2017). Attendance of safety and ergonomic standards at the agricultural tractor operation posts (p. 128, Masters thesis, Universidade de Santa Maria, Santa Maria, RS, Brazil).

Bellochio, S. D. C., Vargas, F. de, Oliveira, M. B. de, \& Alonço, A. dos S. (2017). Brazilian tractors fleet estimation by time of use and sales. Revista Scientia Agraria, 18. https://doi.org/10.5380/rsa.v18i3.54706 
DENATRAN (Departamento Nacional de Trânsito). Retrieved from http://www.denatran.gov.br/index.php/ resolucoes

MTE (Ministério do Trabalho e Emprego). (2005). Portaria $n^{\circ}$. 86, de 03 de março de 2005, NR31. Segurança e saúde no trabalho na agricultura, pecuária silvicultura, exploração florestal e aquicultura.

MTE (Ministério do Trabalho e Emprego). (2010). Portaria $n^{\circ}$. 197, de 17 de dezembro de 2010 , NR12. Segurança no Trabalho em máquinas e equipamentos.

Conceição, T. V. da. (2017). A relação dos motoristas brasileiros com a legislação de trânsito (p. 104, Doctoral dissertation, Universidade Federal do Rio Grande do Sul, Porto Alegre, RS, Brazil).

Correa, I., Yamashita, R. Y., Franco, A. V. F., \& Ramos, H. H. (2005). Checking security requirements for tractors in some regions in the state of São Paulo. Revista Brasileira de Saúde Ocupacional, 30, $25-33$. https://doi.org/10.1590/S0303-76572005000100004

Debiase, H., Scholosser, F. J., \& Pinheiro, E. D. (2004). Development of partial ergonomic and safety coefficient of agricultural tractors. Engenharia Agrícola Jaboticabal, 24, 727-735. https://doi.org/10.1590/S0100-6916 2004000300025

Espíndola, C. J., \& Cunha, R. C. C. (2015). A dinâmica geoeconômica recente da cadeia produtiva da soja no Brasil e no mundo. GeoTextos, 11, 217-238. https://doi.org/10.9771/1984-5537geo.v11i1.12692

Flores, F. J. S., Rinaldi, P. C. N., Alvarenga, C. B. de, Fernandes, H. C., \& Cidrini, I. A. (2015). Accidents with agricultural tractors in Rio Pomba county, Zona da Mata-Minas Gerais state. Revista Agrotecnologia, 6, 102-115. https://doi.org/10.12971/2179-5959/agrotecnologia.v6n1p102-115

Francetto, T. R., Dagio, R. F., \& Ferreira, M. F. (2010). Information provided by the manufacturers of farming tractors in Brazil to make a comparison and a technical selection of the model to be acquired. Paper presented at the ninth Congreso Latinoamericano y del Caribe de Ingeniería Agrícola CLIA 2010 and thirty-ninth Congresso Brasileiro de Engenharia Agrícola CONBEA 2010. Vitória, ES.

Gergoletti, I. F. (2008). Food production: A comparative analysis of scenarios in the perspective of environmental sustainability (p. 191, Doctoral dissertation, Universidade Metodista de Piracicaba, Santa Bárbara d' Oeste, SP, Brazil).

Ferreira Filho, J. B., \& Felipe, F. I. (2007). Crescimento da produção agrícola e o consumo de tratores de rodas no Brasil entre 1996-2005. Paper presented at the forty-fifth Congresso da Sociedade Brasileira de Economia, Administração e sociologia Rural.

Fernandes, C. H., Madeira, N. G., Teixeira, M. M., Cecon, P. P., \& Leite, D. M. (2014). Accidents with tractors: nature, causes and consequences. Revista Engenharia na Agricultura, 22, 361-371. https://doi.org/ 10.13083/1414-3984.v22n04a08

Greenan, M., Toussaint, M., Peek-Asa, C., Rohlman, D., \& Ramirez, M. R. (2016). The effects of roadway characteristics on farm equipment crashes: A geographic information systems approach. Injury Epidemiology, 3, 1-16. https://doi.org/10.1186/s40621-016-0096-1

Matos, P. F., \& Pessôa, V. L. S. (2011). A modernização da agricultura no Brasil e os novos usos do território (Ano 13, Vol. 2, No. 22, pp. 290-322). Geo UERJ, Instituto de Geografia da Universidade do Estado do Rio de Janeiro.

Melo, H. M. de, Nagaoka, A. K., \& Vieira, F. C. (2012). Influence of agricultural subsidies and new technologies trends in the Brazilian wheeled tractors commercialization. Revista de Ciências Agroveterinárias, 11, 70-76.

Molin, J. P., Amaral, L. R., \& Colaço, A. F. (2015). Agricultura de Precisão (1st ed.). Oficina de Textos, São Paulo, SP.

Monteiro, L. A., et al. (2010). Caracterização dos Acidentes Graves Ocorridos na Zona Rural na Região do Centro Oeste Paulista. Paper presented at the Thirty-Ninth Congresso Brasileiro de Engenharia Agrícola. Vitória, ES.

Monteiro, L. (2014). Acidentes com máquinas agrícolas matam mais que automóveis e motocicletas. Revista Proteção, 12. Retrieved from http://www.protecao.com.br/noticias/geral/acidentes_com_maquinas_agric olas_matam_mais_que_automoveis_e_motocicletas/AQjyAAjy/7565

Oliveira, M. D. M. (2000). Operational cost and renewal point of agricultural tires tractors: Evaluation of a fleet (p. 145, Masters thesis, Universidade de São Paulo, Piracicaba, SP, Brazil). 
OIT (Organización Internacional del Trabajo). (2004). Panorama Laboral 2004: Oficina Regional para las Américas y el Caribe (p. 118). Oficina Internacional del Trabajo, Lima, Peru. Retrieved from http://ilo.org/ wcmsp5/groups/public/---americas/---ro-lima/documents/publication/wcms_187467.pdf

Ramirez, M., Bedford, R., Wu, H., Harland, K., Cavanaugh, J. E., \& Peek-Asa, C. (2016). Lighting and marking policies are associated with reduced farm equipment-related crash rates: A policy analysis of nine Midwestern US states. Occupational and Environmental Medicine, 73(9), 621-626. https://doi.org/10.1136 /oemed-2016-103672

Rinaldi, P. C. N., Fernandes, H. C., Teixeira, M. M., Cecon, P. R., \& Alvarenga, C. B. de. (2016). Diagnosis on the power and torque of agricultural tractors manufactured and commercialized in Brazil. Revista Engenharia na Agricultura, 23, 246-256. https://doi.org/10.13083/reveng.v24i3.644

Silva Junior, J. J. (2017). Transformações da agricultura e pesquisa agrícola no Brasil (189 f., Doctoral dissertation, Instituto de Economia da Universidade Estadual de Campinas, Campinas, SP, Brazil).

Silva, R. A. (2015). Human limitations operator of agricultural machinery and the social and work environment in soybeans (p. 75, Doctoral dissertation, Universidade Estadual Paulista, Câmpus de Jaboticabal, SP, Brazil).

Vian, C. E. de F., Andrade Junior, A. M., Baricelo, L. G., \& Silva, R. P. (2013). Origens, evolução e tendências da indústria de máquinas agrícolas. Revista de Economia e Sociologia Rural, 51, 719-744. https://doi.org/ 10.1590/S0103-20032013000400006

Vieira Filho, J. E. R., Gasques, J. G., \& Sousa, A. G. (2011). Agricultura e crescimento: Cenários e projeções (p. 38). Instituto de Pesquisa Econômica Aplicada, Brasília. Retrieved from http://www.ipea.gov.br/ portal/images/stories/PDFs/TDs/td_1642.pdf

\section{Copyrights}

Copyright for this article is retained by the author(s), with first publication rights granted to the journal.

This is an open-access article distributed under the terms and conditions of the Creative Commons Attribution license (http://creativecommons.org/licenses/by/4.0/). 